\title{
In Quest of the Good Urban Life: Socio-spatial Dynamics and Residential Building Stock Transformation in Zurich
}

\author{
Martina Koll-Schretzenmayr, Frank Ritterhoff and Walter Siebel
}

[Paper first received, July 2006; in final form, October 2008]

\begin{abstract}
This paper discusses socio-spatial dynamics and the transformation of the residential building stock in the global city of Zurich. It deals with five questions. Does Zurich exhibit the type of social polarisation outlined by the global city hypothesis? If so, how does social polarisation become visible in the context of a European city? Which actors in the real estate market are catering to the special tastes of the new urban middle class? With whom does the new middle class compete for space in the city? The paper argues that real estate developers customise the residential building stock and produce residential units for a targeted market - the new urban middle class. Furthermore, a new socio-spatial phenomenon - ennoblement - has evolved, as the new urban middle class takes residence in traditional upper-class neighbourhoods. By investing its own economic capital, this new middle class is hoping to profit from upper-class social and cultural capital.
\end{abstract}

\section{Introduction: Leading Questions, Case Context and Data Inputs}

In her seminal work of 1991, The Global City, Saskia Sassen outlined the thesis that economic growth, driven by the new complex of finance and specialised services, has transformed the social and economic structure of 'global cities'-i.e. those cities that "play a key role in the control and co-ordination of international capitalism" (Hamnett, 1994, p. 401). These global (Sassen, 1991) or world (Friedmann, 1986) cities exhibit an increase

Martina Koll-Schretzenmayr is in the Netzwerk Stadt und Landschaft, ETH Zurich, ETH Hoenggerberg, Zurich, CH-8093, Switzerland. E-mail: Schretzenmayr@nsl.ethz.ch.

Frank Ritterhoff is in the TU Berlin, Institut für Soziologie, D-10587 Berlin, Germany. E-mail: frank.ritterhoff@tu-berlin.de.

Walter Siebel is in the Institut für Soziologie, Carl von Ossietzky Universität, Oldenburg, Germany. E-mail: walter.siebel@uni-oldenburg.de. 
of both high-income and low-income workers, which results in greater occupational and income polarisation and constitutes both a social and socio-spatial polarisation (Friedmann and Wolff, 1982; Friedmann, 1986; Sassen, 1991, 2001).

This process is driven by a new metropolitan actor: the affluent consumptionoriented class of high-income workers. These members of what could be called a new urban middle class are characterised by three traits that make them a new and important actor in the development of cities: rapid numerical growth, a concentration in city centres (Sassen, 2001, p. 286) and lifestyles that are different from those led by either the suburban middle classes or the traditional upper class (grande bourgeoisie).

There is still little literature on socio-spatial processes that are linked to the influx of the new urban middle class into the global city and its impact on the cityscape, especially with regard to Europe. The main thesis associated with this process is that of social and socio-spatial polarisation. Yet does this also hold true for European cities? Who produces the built environment that conforms to the lifestyle and housing preferences of the new urban middle class? How do the members of this new middle class change existing neighbourhoods? Where exactly do they settle and what are the social classes they are competing with for residence? Against this background, this paper is guided by five questions

(1) We explore social polarisation in the city of Zurich. Does Zurich exhibit the type of social polarisation outlined by the global city hypothesis (Friedmann and Wolff, 1982; Friedmann, 1986; Sassen, 1991, 2001)?

(2) If so, what does social polarisation mean in the context of a European city-i.e. is there a corresponding socio-spatial polarisation?
(3) How does the spatial distribution of investment in the residential building stock correlate with social change and the physical transformation of the building stock? For this purpose, we link changes in the residential building stock to changes in the respective neighbourhood's social profile.

(4) We identify the main actors who produce and remodel the residential building stock, and who are therefore responsible for the impressive physical change of Zurich's cityscape. What kinds of actors in the real estate market are serving the special urban taste of the new urban middle class?

(5) Where, in the course of the new urban middle class's influx, is investment in the residential building stock concentratedi.e. with whom do they struggle for space in the city? Is it only the lower class as the gentrification hypothesis states, or do they also try to invade the strongholds of the traditional upper class, the grande bourgeoisie?

In a concluding section, we discuss the results and summarise the main findings.

This paper explicitly focuses upon the city of Zurich for two main reasons. First, because Zurich is ranked as a European global city. With its 370000 inhabitants (30 per cent foreigners), 330,000 employees (of whom 89 per cent are employed in the services sector) and 195000 dwellings, the city of Zurich is the inner core of a city-region of approximately 3 million inhabitants. It is also the largest and economically most powerful city in the polycentric urban system of Switzerland. Beyond the two major global players, UBS and Credit Suisse Group, there are about 410 Swiss and international financial services firms and 92 banks headquartered in the Zurich city-region. Swiss banks currently manage one-third of the world's private assets invested abroad. Nearly 50 per cent of 
the city of Zurich's tax revenues originate in the financial services sector. Moreover, Zurich is the world's third-largest insurance market and the Swiss stock exchange is the world's eighth-largest. In addition, Zurich is a global player in key technologies: information and communication technology (ICT), life sciences and high tech. Last but not least, during the past few decades, Zurich has become one of the leading global centres of the art market, with a significant number of internationally well-established galleries.

Since the world city hypothesis was formulated, Zurich has been classified as a 'world city' (Friedmann, 1986). In the world city networks survey by Taylor et al. (2002), Zurich ranks as one of the 21 global command centres housing the headquarters of a set of 100 global service firms that have offices in at least 15 different cities and with at least one office in each of the three prime global markets: North America, western Europe and Pacific Asia. Furthermore, Taylor et al. (2002) classify Zurich as a gateway to emerging markets, a new strategic location from which firms choose to expand their geographical reach. In his latest survey, Taylor (2005) classifies Zurich as a 'world-wide leading city'.

Secondly, Zurich was chosen because of the quality of the data available at a very low level of aggregation. We thereby concentrate our research on the city of Zurich without taking into account the processes in the wider region. Concentration on this arguably small area can be justified by our interest in shedding light on the upper end of the social strata. The new 'gentry' of the late 20th and early 21 st centuries are supposed to be mainly interested in living at the core of the metropolitan region, which is represented by the city of Zurich.

\section{Social Polarisation in the City of Zurich}

Although it is widely accepted that the phenomenon of social polarisation is distinct from other concepts of social inequality, empirical studies are not always explicit in defining the term social polarisation (Walks, 2001; Hamnett, 1994). The Gini coefficient and the income ratio, two classical indices of inequality, both measure income inequality in a given population. These measures describe income inequality as a widening gap between poor and rich. In contrast, the concept of polarisation describes an increase of both the poor and the affluent strata, or of unskilled and highly qualified jobs, parallelled by a decrease of the middle strata (Zhang and Kanbur, 2001; Rhein, 1998, p. 430), a movement towards a so-called hourglass society (Marcuse, 1989). In order to distinguish the two concepts of inequality it is important to note that polarisation does not necessarily imply a widening of the gap between the poles, but a concentration of the population at the two poles, regardless of how far apart they are.

In the context of this paper, 'polarisation' is treated as a process where the middle class is at the very least shrinking in relative terms. In other words, over a certain period of time, the number of 'rich' and 'poor' residents grows faster than the number falling into the 'middle' (Mollenkopf and Castells, 1991, p. 407). Harrison and Bluestone (1988) introduce a method for the measurement of polarisation that captures the changing proportion of workers with earnings less than half the median (i.e. low-income earners) or over twice the median (i.e. high-income earners) over a particular period of time. We used this measurement for our Zurich case study.

We examine polarisation at two levels within the city of Zurich: social polarisation at the level of the city as a whole and socio-spatial polarisation at the level of 209 municipal tracts. The relationship between sociospatial change and building stock change has been analysed at the level of the municipal tracts as well. Three variable groupings are used in this research: socio-professional status, nationality and income. 
First, the socio-professional status data from the 1990 and 2000 census, made up of the person's highest educational attainment, current occupation and professional status, is used. It has been grouped into 'high-qualification professions' (senior management, graduate professions, liberal professions), 'medium-qualification professions' (intermediary professions, qualified nonmanual professions, qualified manual professions) and 'low-qualification professions' (unqualified employees and workersi.e. without occupational training).

Secondly, the national variable group has been divided into low-status and high-status foreigners. The 'low-status migrants' group comprises foreigners from Portugal, former Yugoslavia, Croatia, Bosnia-Herzegovina, Turkey, Latin America, Asia and Africa. This grouping is strongly supported by recent research on the correlation between socioprofessional status and the income of foreigners in Zurich (Heye and Leuthold, 2004, p. 24; Statistik Stadt Zürich 2005a, 2005b).

Thirdly, the income variable is based on the mean taxable income per tax-payer. In this context, one must take into account that the time-period analysed covers the collapse of the new economy boom in 2002. Hence, one can assume that an analysis of the following years might reveal lower values up to 2005 and higher values if one includes the years from 2006 when stock markets once again saw sharp price increases. The socio-professional variable group is based on 1990 and 2000 census data, whereas the income variable and the foreign nationality variables are datasets sourced from the Statistical Office of the city of Zurich available for 1993 and 2002.

The proportion of highly qualified individuals in Zurich's economically active population rose from 25000 to 35000 (or from 12.4 per cent to 17.5 per cent) between 1990 and 2000. Thus the group of highly qualified urbanites grew considerably in both absolute and relative terms. Between 1991 and 2002, there was a rise in the number of Zurich residents in the top income tax bracket, from 1.23 per cent of all tax-payers to 1.6 per cent, while the proportion of residents in the lowest tax bracket has more than doubled, from 5.0 per cent to 10.1 per cent. The trend towards polarisation is even more pronounced when it comes to net worth, although much of this has been driven by the large movements in the stock market during the observed timeframe. The number of low-status migrants rose during the observed time-frame from 43330 (1993) to 54675 (2002), which corresponds to an increase from 12.1 to 15.2 per cent of the total population. Together with the increased number of unemployed people in the city of Zurich, these numbers are evidence that there is both absolute and relative growth at the bottom pole of the income spectrum. Overall, the data support the social polarisation thesis for the case of Zurich. ${ }^{1}$

\section{Socio-spatial Polarisation in the City of Zurich}

According to the classical assumption of urban sociology, that the social structure of urban society leaves its marks on the cityscape, social polarisation must lead to socio-spatial polarisation. Thus it should be expected that in global cities the number of middle-class neighbourhoods will decrease and, in parallel, the number of both affluent (or gentrified) and deprived neighbourhoods will increase.

The analysis of socio-spatial polarisation has been conducted at the level of municipal tracts, dividing the city area as a whole into 212 statistical sub-divisions. Based on a comparison of 1990 and 2000 census data, only 209 tracts could be included in the analysis because a reorganisation of municipal tracts had taken place between 1990 and 2000. Although municipal tracts provide 
a low level of aggregation, one can assume that homogeneous neighbourhoods may be transected by municipal tracts and that municipal tracts may contain several small socially homogeneous neighbourhoods. In both cases, the true extent of segregation might be underestimated.

Based on the social polarisation variable groupings described earlier, we constructed six social area categories. For the analysis of socio-spatial polarisation, the number of municipal tracts within the different social area categories was compared for 1990/93 and 2000/02 respectively.

The six 'social area categories' are

- Low-status migrants: tracts within this category exhibit a comparatively high percentage of low-status migrants.

- Low-status migrants in disadvantaged neighbourhoods: the characteristics of this category are a high percentage of lowstatus migrants, a low percentage of highly qualified inhabitants and/or a low level of mean taxable income per tax-payer.

- Swiss working class: tracts of this category are typically characterised by a low level of mean taxable income per tax-payer, a low percentage of highly qualified inhabitants and, in most cases, a low percentage of low-status migrants - i.e. a high percentage of Swiss residents.

- Intermediate: tracts in this category exhibit mainly medium values of all variables. Tracts characterised solely by a low percentage of low-status migrants or highly qualified inhabitants that in other respects exhibited medium variable values have been assigned to this category.

- Transnational élite: the characteristics of this social category area are a high percentage of highly qualified inhabitants and/or a high level of mean taxable income per tax-payer. At the same time, the percentage of low-status migrants is low. The 'transnational élite' relates to Friedmann's and Wolff's (1982, p. 322) "primary cluster of high-level business services which employs a large number of expatriate professionals".

- Swiss élite: tracts in this category differ from the 'transnational élite' in exhibiting a very high percentage of Swiss inhabitants.

This social area categorisation, created using cluster analysis, essentially corresponds to the 'mental maps' of Zurich as seen through the eyes of its inhabitants and its real estate investors (see van Wezemael, 1999).

The number of low-status neighbourhoods, consisting of the first three categories, rose by a small margin from 43 to 45 . At the other end of the scale, the number of residential areas that can be assigned to highstatus neighbourhoods (i.e. transnational and Swiss élite) increased in the observed time-period from 23 to 33 . While 143 of the 209 tracts could be assigned to the intermediate' group in $1990 / 93$, by $2000 / 03$ there were only 131 tracts left. This is evidence of a strong, but shrinking, middle stratum-in contrast to the number of tracts consisting of the polarised groups.

To summarise, we found a highly dynamic socio-spatial cityscape during the 1990s. An additional 10000 highly educated inhabitants had to find a home. While there is clear evidence of a growing upper stratum that manifests itself spatially, the evidence of growth at the bottom end is less clear. In principle, these findings are in line with the world city theory's hypothesis of sociospatial polarisation. However, in the case of Zurich, the growth is one-sided-i.e. only at the top end. This might partly be an outcome produced by utilising municipal data. However, it is still astonishing how persistent the middle-class areas seem to be and how small the rise is at the lower end-a point taken up in the conclusion. 


\section{Social Transformation and Physical Change}

The interdependence between the change in social structure and residential building stock has been extensively discussed in the context of the world city hypothesis (Friedmann and Wolff, 1982; Friedmann, 1986; Sassen, 1991, 2001) and, moreover, linked to the wellresearched phenomenon of gentrification. This theory suggests a spatial relation between investment in the residential building stock and upward social mobility. It follows that the influx of well-educated high-income workers to the city of Zurich between 1990 and 2000-and their need for appropriate residential units - must have initiated investment in the residential building stock and with it physical change of the cityscape. These changes will have been manifested by new development, renovations and, last but not least, by demolition that produces developable plots in certain parts of the city.

The Statistical Office of the city of Zurich provides information on new buildings, demolished buildings and the renovation of buildings. ${ }^{2}$ For the purpose of this analysis, the geo-coded database, which contains information about each single building in the city of Zurich, has been aggregated to the municipal-tract level. We then related a municipal tract's social profile and 'social career' to the physical change in its residential building stock. Physical changes in the residential housing stock of a municipal tract, as utilised in Tables 1-3, are measured by the percentage of the 2002 residential housing stock (measured by the building volume in cubic metres) that has been newly built or renovated between 1993 and 2002, and the percentage of the 1993 residential housing stock that has been demolished between 1993 and 2002. In the city of Zurich, undeveloped land available for the construction of new buildings is a scarce commodity, such that demolishing old buildings is a common means of freeing built-up parcels for new development. Hence the analysis of demolition, construction and renovation indicates upward physical change. However, the datasets of the Statistical Office of the city of Zurich do not permit the measurement of downward physical change as a result of disinvestment.

The link between physical change in the residential building stock and an area's 'social career' was determined by comparing the respective social area categories of each tract in 1990/93 and 2000/02, and assigning the tracts to 'advancement' (positive social trajectory), 'relegation' (negative social trajectory) or 'stationary' (no change in social status). Because the different social area categories differ widely in their rates of physical change, comparison of 'advancement', 'relegation' and 'stationary' is conducted only within the same social area category, although this reduces the number of cases that can be compared. As a consequence, comparison can only be provided for the following social area categories: 'low-status migrants in disadvantaged neighbourhoods', 'intermediate', and 'Swiss élite'.

Table 1 compares the dynamic in the residential building stock of tracts that were assigned to 'low-status migrants in disadvantaged neighbourhoods' in 1993. Tracts of this social area category that changed their social profile in a significant way (i.e. immediate or higher in 2000/02) were classified as 'advancing'. Since 'low-status migrants in disadvantaged neighbourhoods' is already the lowest social area category and no further downward movement of the social profile is possible, the tracts not advancing are classified as 'stationary'.

As could be expected, our findings demonstrate that the socially advancing tracts are accompanied by a greater dynamic of construction than the 'standstill' tracts. The percentage of renovations in the former is twice as high as in the latter, new construction 


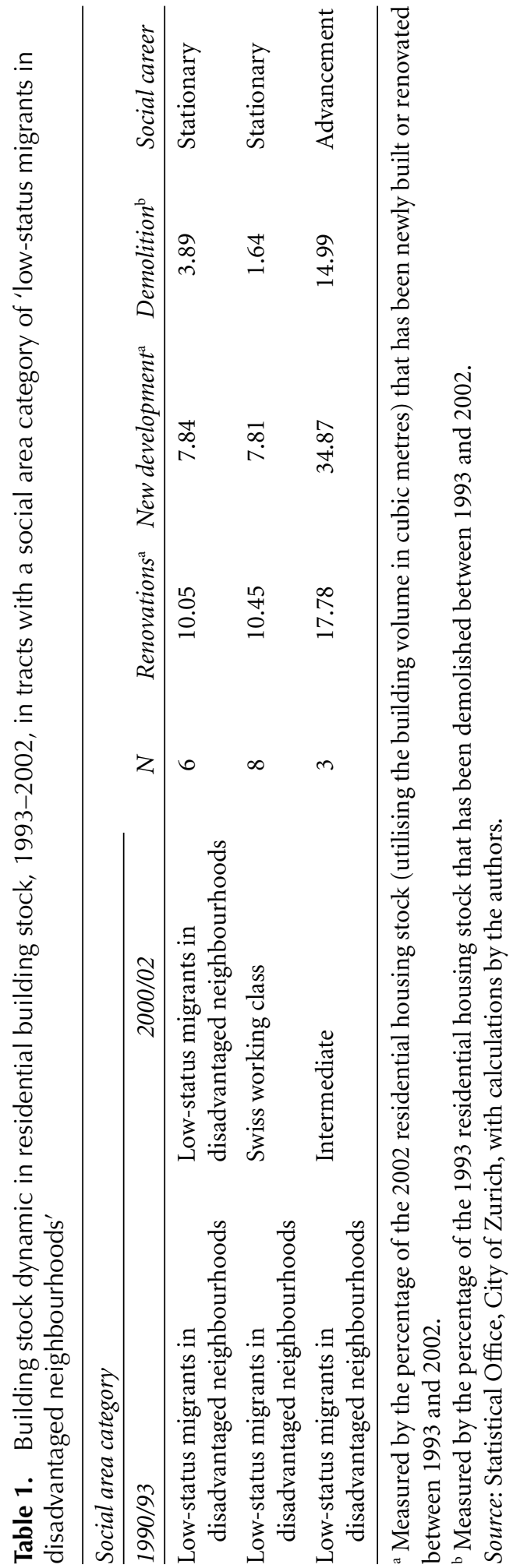

is about five times higher and the percentage of demolitions about six times higher. These results support the hypothesis that the two processes of social change and physical change are correlated: the greater the social change, the more it is accompanied by building activity.

The same connection can be seen again for the 'intermediate' social area category in Table 2: the higher the increase in the social status, the higher the physical change. Yet in contrast to Tables 1 and 3, a movement in both directions - up and down-is possible and the differences between ascending and descending tracts are the most obvious. The seven tracts that experienced advancement from 'intermediate' to 'Swiss élite' are the tracts that experienced by far the highest building stock dynamic. They are even distinct from those tracts that in 2000/02 were assigned to the 'transnational élite' (three times the rate of renovation and three times the rate of new construction). A clear connection between building stock dynamic and social change is also demonstrated by the clear differences between those tracts whose profile had been unchanged and those that have experienced decreasing social status. In particular, the lower rate of new constructions in the latter case catches the eye. As can be expected, the physical deterioration of an area occurs when owners do not invest in their properties, and this is most likely to occur when the inhabitants' purchasing power is low and there is no chance of a future increase in their social status.

Clearly, members of the 'Swiss élite' group cannot improve their social status further. Thus we can only check on the difference in building stock dynamics between the 'relegation' and 'stationary' categories. The differences in the dynamic of new construction and demolitions are minor. However, they are in the expected direction-i.e. the building stock dynamic is slightly lower for the tracts that exhibit relegation tendencies than for 


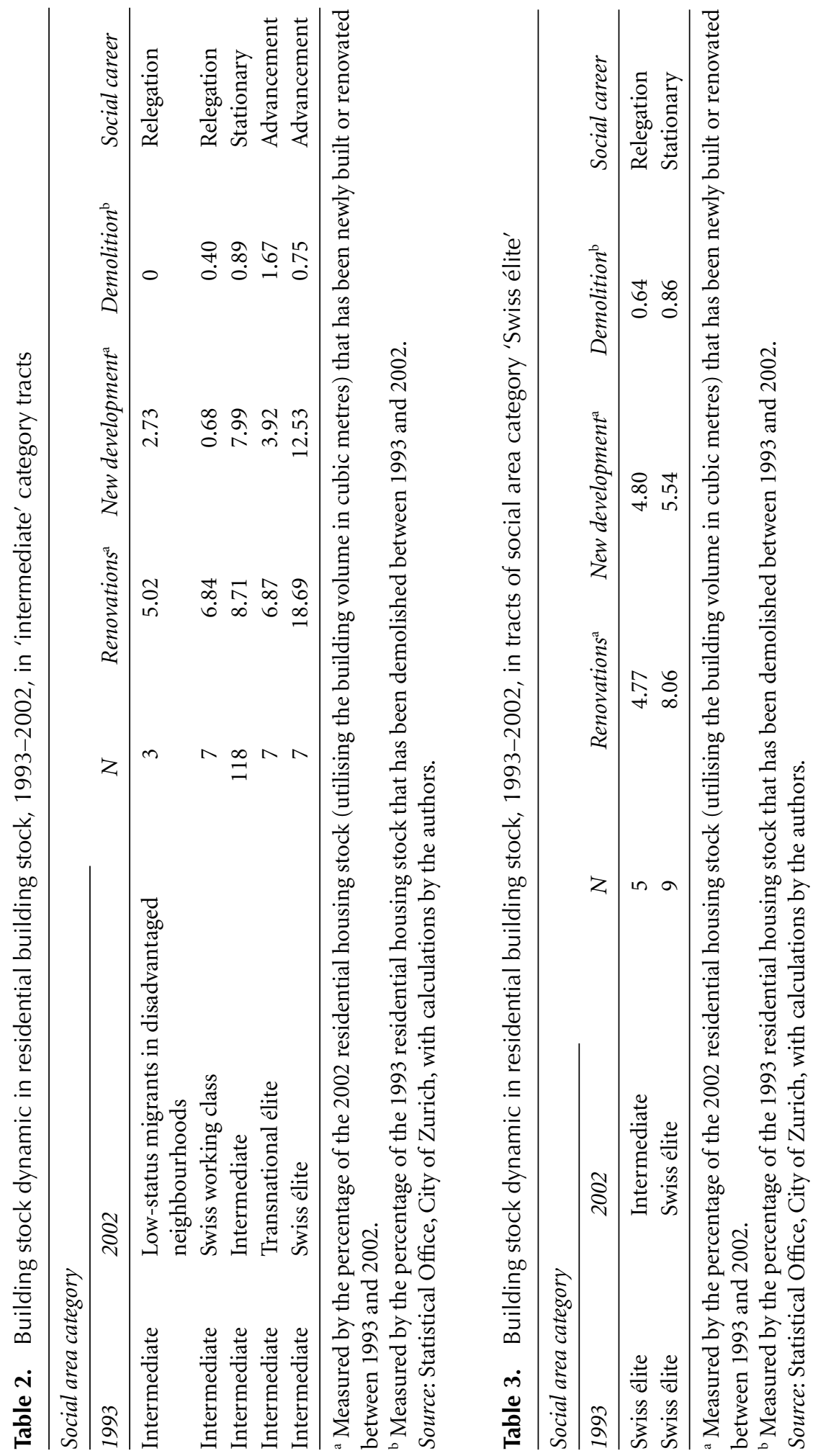


the tracts that do not experience social change. Only the renovation dynamics are easily distinguishable from one another.

Overall, the data presented support the highly plausible hypothesis that a strong correlation exists between building stock dynamics and social change. This correlation is especially strong in the areas that experienced upward social mobility. In contrast, descending areas experience a very low rate of investment.

\section{The Actors Behind Urban Change}

The expansion of the new urban middle class is the driving factor behind these social and physical changes. However, in the main, they do not remodel the city's physical landscape themselves. Who are the 'real' actors behind urban change-i.e. those who customise the residential building stock and produce residential units aiming to appeal to the affluent new urban middle class? Four types of actor can be distinguished in Zurich's real estate market: individual or co-owner proprietors, the city of Zurich (as proprietor of the residential building stock), (non-profit) housing co-operatives and real estate corporations. ${ }^{3}$ Using the building stock datasets from the Statistical Office of Zurich (see earlier), for each single municipal tract we are able to evaluate the share of each actor group in the total renovation activities and in new developments within the residential building stock.

For new developments, the most important actors are real estate corporations. They initiated 27 per cent of all new developments in the city of Zurich as a whole (measured in building volumes). However, their share within the municipal tracts of increasing socioeconomic status is considerably larger-i.e. in those tracts that changed from 'lowstatus migrants in disadvantaged neighbourhoods' in 1990/93 to 'intermediate' in
2000/02, approximately 99 per cent of all new developments were initiated by real estate corporations. In the other two social area categories exhibiting increasing social status, the respective rates are 51 per cent ('intermediate' to 'transnational élite') and 63 per cent ('intermediate' to 'Swiss élite'). This domination is even more impressive if we add to this the bulk of the new condominiums. These are normally initiated not by end-users but by professional real estate developers. Of the city-wide new residential building stock, 13.3 per cent was registered as 'condominium', with a peak of 41.5 per cent in municipal tracts that remained in the 'Swiss élite' social area category. Their share in the city of Zurich in 2005 was at 6.6 per cent of the residential unit stock, an increase of two-thirds over the past 10 years.

The city of Zurich as an owner of residential units accounts for 2 per cent of all new developments within the city limits, individual and co-owner proprietors for 20 per cent. The housing co-operatives hold a city-wide share in new-built housing of about 17 per cent. The majority of new construction activity by co-operatives could be observed in tracts that belonged in 1990/93 to the 'intermediate' social area category. Housing co-operatives are therefore still a broad 'traditional middleclass phenomenon' in Zurich.

For renovation activities, the main actors are individuals or co-owners. In general, they do not exhibit a distinct preference for neighbourhoods with increasing socioeconomic status (although a slight fondness of this ownership category for renovation activities in tracts that had already been categorised as 'transnational élite' or 'Swiss élite' in 1990/93 is observable). Instead, real estate corporations once again concentrate their activities on promising neighbourhoods. Conducting about 15 per cent of all renovation activities in existing buildings in Zurich, they are less active in this field than in that of new developments. However, the real estate 
corporations are especially active in tracts of increasing socioeconomic status: 17.9 per cent of all renovations in 'intermediate' to 'transnational élite', 48.5 per cent in 'intermediate' to 'Swiss élite' and 60.7 per cent in 'low-status migrants in disadvantaged neighbourhoods' to 'intermediate'.

Deeper analysis reveals that, as far as renovations are concerned, real estate corporations do have a special preference for investing in the renovation of buildings built before 1919 . This particular housing stock is historically concentrated in specific areas of Zurich and is considered especially attractive for the highly qualified affluent workers.

To summarise our findings: real estate corporations are the main actors in remodelling the built environment of Zurich according to the tastes of the new urban middle class. By concentrating their activities on areas with increasing socioeconomic status, they invest in new developments as well as renovating tasteful residential buildings from the 19th and early 20th centuries for the highly qualified new urban middle class in promising neighbourhoods

\section{Striving for the Good Urban Life and the Battle for Urban Space}

Whether it is the 'class of highly qualified service workers' in the context of the 'service society' (Häussermann and Siebel, 1995), Sassen's $(2000,2001)$ 'new class of highincome workers' in global cities or Florida's (2005) 'creative class' linked with the new knowledge-based economy, the most obvious phenomenon is the emergence of an affluent group of urban actors who are distinct from both the traditional suburban middle class and the grande bourgeoisie.

Summing up authors like Zukin (1987), Sassen (2001) and Florida (2002), it is possible to argue that this new class of affluent urbanites substantially alters not only the social and physical but also the cultural urban landscape of global cities.

Hence the importance not just of food but of cuisine, not just of clothes but of designer labels, not just of decoration but of authentic objets d'art. ... the ideal residence is no longer a 'home' in suburbia, but a converted former warehouse in ultra-urban downtown (Sassen, 2001, p. 341).

This change reaches beyond the residential building stock. The striving for the good urban life in the form of consumption, social diversity, aesthetic promiscuity, hedonistic lifestyle and sub-culture results in a perceptible increase in bars, restaurants, clubs and the cultural economy. These processes of urban change are usually conceptualised as 'gentrification'. Originally coined by Ruth Glass in 1964, the term gentrification has since then been linked with the intrusion of better-off classes in run-down neighbourhoods, with their socioeconomic and physical upgrading into "new wealthy inner-city enclaves" (van Criekingen and Decroly, 2003, p. 2456) and with the driving-out of the former poorer inhabitants (unless dealing with the special case of incumbent upgrading). However, the new urban middle class is not only displacing the urban poor in order to generate desirable living spaces. A closer look at the areas where the new urban middle class is settling shows that two distinct types of area are emerging in Zurich.

The vibrant Zürich West is an example of the first type - an area west of the city centre that has undergone the transformation from urban industrial heartland to a trendy new district. The processes observable in Zürich West are dominated by gentrification of brownfield sites driven mainly by new-build housing that primarily attracts the more bohemian clientèle of the new urban middle class. This development is also fuelled by the massive influx of the creative industries 
that has established itself in this area since the 1990s due to the proximity of art colleges, as well as affordable lofts and studios in old industrial buildings close to the CBD.

Zürichberg is an example of the second type. This highly valued traditional upperclass quarter of Zurich is dominated by detached housing from the late 19th and early 20th centuries. The grande bourgeoisie kept control over this environment for a long period of time, staying in the inner core of the area. Zürichberg is priced at the top end of the market with house prices rising dramatically; rising prices in an already-highprice area can be interpreted as a sign of the successful defence of a good address. Yet it is not only economic power. Paraphrasing Bourdieu (1983/1992), Pinçon and PinçonCharlot (2000) point out that it is precisely the very combination of economic, cultural and social capital, which defines the strength of the grande bourgeoisie. ${ }^{4}$ They termed the process of creating, organising and defending the 'beautiful neighbourhoods' by investing economic, social and cultural capital 'la griffe spatiale'.

According to Le Galès (2002, p. 127) the families of the grande bourgeoisie still have the power to protect their neighbourhoods from nouveaux riches invaders. Following the thesis of la griffe spatiale, the members of the new urban middle class should not be able to buy a home in Zürichberg. However, the fate of Zürichberg offers evidence for a loosening griffe spatiale of the grande bourgeoisie over their traditional homesteads. The whole area has been dramatically 'enhanced' during the past two decades, with a peak in the housing market over the past 5-10 years. These market dynamics have been tied to physical change as well. They have been continuing recently. For example, in the inner core of Zürichberg the number of dwellings increased from 19152 in 2004 to 19352 in 2006 (+200 dwellings). The 'condominiumisation' of Zürichberg includes the mobilisation of vacant lots and new-build infill housing, as well as the demolition of 'unsuitable' housing stock, especially in areas dominated by detached buildings. These offer the opportunity to produce plots that can be developed with a view to maximising profits with respect to the floor area ratio. Recently, in the Zürichberg area even estate gardens belonging to old mansions have been covered with condominiums. The multiplying of condominiums in the Zürichberg area is an answer to the increasing demand for housing units suitable for the distinctive residential and budgetary requirements of the new urban middle class. Their growth resulted from the move of high-income workers into this privileged bourgeois residential area since the 1990s, thus getting into competition with the established grande bourgeoisie for the most favoured addresses.

\section{Discussion and Conclusions}

Overall, there is strong evidence of social polarisation (see section 2), but scarce evidence of socio-spatial polarisation in the city of Zurich (see section 3 ). In addition, our data demonstrate a clear positive correlation between the social career of an area and the amount of investment in the built environment (see section 4). Furthermore, there is evidence that private real estate developers have been the dominant actors accounting for the housing dynamics of the city of Zurich during the past one and a half decades (see section 5). The share of these professional developers is distinctly higher in the promising neighbourhoodsi.e. in tracts that experienced an upward 'social career' or were already at the top. As the new urban middle class has flowed into the city, the role of real estate developers able to customise the residential building stock to the requirements of this affluent new class has become distinctly more important. 
Between 1990 and 2000, the nature of social dynamics is marked by the expansion of the upper social strata. Therefore, the social polarisation processes observed are in line with the global cities paradigm. However, the patterns of socio-spatial dynamics in Zurich are in contrast to the picture painted by Saskia Sassen. Neither slums, nor ghettos, nor fortified enclaves nor gated communities can be found in Zurich. The structural upgrading taking place in Zurich more probably contributes to an upgrading of the entire city and to a desegregation of low-status migrants. Particularly in housing areas with the highest share of low-status migrants, intensive building activity has led to a decrease in their numbers, but without a detectable appearance of higher concentration in other quarters.

A first explanation for these results lies in the limited scope of our research. Our data refer only to the city of Zurich. Some of the changes, especially at the lower end of the social strata, could have taken place beyond the city limits. To analyse the processes of socioeconomic change more adequately would require further research on a regional database. $^{5}$

A second explanation could be that Zurich, contrary to relevant literature, is not a global city after all. Clearly, it lacks global city status in the sense enjoyed by New York (Hill and Kim, 2000). Also, Zurich does not have the racial problems of US cities. Additionally, it could be mentioned that Switzerland's historical, non-central-city system and its firmly federal national structure all restrict a one-sided concentration of command functions in one city. However, against this second explanation it could be argued that it is not that relevant whether Zurich is a global city or not, because social polarisation in any case ought to show itself more clearly than is apparent from the researched data, as polarisation basically can be considered a phenomenon of developed service-economy cities - and, without a doubt, Zurich falls into this category.

Thirdly, historical and cultural characteristics particular to Switzerland can be invoked. The lack of a monarch as well as the non-existence of an aristocracy made it possible for a bourgeois middle class to develop into a culturally and politically dominant power. Since the 18th century, Switzerland has developed into one of the most successful European bourgeois societies, whose basic principles and values are today still deeply ingrained (Dahrendorf, 2005). In addition, despite the persistence of exclusionary mechanisms, first affecting the working class, then women and now immigrants, Swiss society exhibits today a "remarkable openness and notable integration potential" (Hettling, 1998, pp. 229; Tanner, 2005). Therefore, Zurich's city politics have for a long time been explicitly oriented towards social and spatial integration.

The fourth explanation for this discrepancy lies in the role of the European welfare state. Unlike, for example, the US, in Europe the negative effects of the structural changes in the economy are noticeably less visible within the formal employment market. Trade union wage politics and the social insurance system ensured a long-term stabilisation of a broad middle class. Yet under conditions of economic structural change this stabilisation has a Janus face: on the one hand, trade union wage politics reduce the size of the low-income sector and, on the other hand, welfare state provisions facilitate economic survival in the absence of paid employment. Hence, the form in which the costs of the structural economic changes become visible is not low-wage labour inside the labour market, but exclusion in unemployment and informal forms of work (Häussermann and Siebel, 1995; Hamnett, 1996a, 1996b, 2003; Kronauer, 2002).

The reason why this exclusion has to a large extent remained invisible in the city structure 
has to do with the role of the European welfare state and with the social housing politics in particular. These have created and maintained a segment of housing provision unrelated to the market (among others, social housing, accommodation allowance and cooperatives). Until today, this has successfully prevented the careers people have in the labour markets from determining their status in the housing market, as is the case in US cities. In 2003, about 37300 out of a total of 200600 apartments in the city of Zurich were owned by co-operatives and another 14700 by public institutions. Thus the share of market-distant segments of the housing market amounts to one-quarter. In addition to that, the unemployment rate in Zurich, as in the whole of Switzerland, is at the lowest edge of the range when compared with other industrial nations.

A fifth and perhaps most important explanation is based on the particular features of the European city. The European city is not only a welfare state-regulated but also a regulating city; whereas the US city is a 'market city' (Marcuse, 2004). Since the Middle Ages, communal administrations in Europe have considered it their responsibility to see that the social, economic and physical development of the city takes place in an orderly and appropriate manner. And the European city is the place from which the bourgeoisie originates. This is the basis for a politically and economically very influential stratum of burghers committed to maintaining the testimony of their own history for the benefit of the city. In the middle of the 1980s, a referendum prevented the construction of skyscrapers in Zurich. This has prevented the development of a dense central business district, as can be found in other global cities (such as New York City, London, Tokyo or Frankfurt/Main). Apparently the burghers of Zurich have firmly embodied the traditional form of the European city in their concept of their city's identity. The dimension of this political foundation in European cities is shown in the presence of history and collective memory. It reveals itself impressively in the protection of historical monuments, provided with substantial money and appeal. Extensive funding of urban renewal has been supported by the tradition of the welfare state. It is thus the double tradition of the European city as a socially responsible political subject of its own development and as a place of emancipation for the citizens (Siebel, 2004) that up to now has effectively prevented the transformation of social polarisation into the socio-spatial structure of the city on display in US cities.

The phenomena recently observed in the traditional bourgeois neighbourhood of the Zürichberg show that la griffe spatiale of the grande bourgeoisie is diminishing (see section 6). Two explanations are plausible. First, during the past few years, the value gap in the real estate market of Zürichberg has increased tremendously. As the replacement of residential building stock and the development of estate gardens becomes more and more profitable, even conservative bourgeois proprietors are tempted into the marketplace. Some of the landlords participating in the dynamic property market by customising their property to the new urban middle class demand even seem to be in need of transferring (parts of) their inherited property to liquid assets in order to be able to hold their inheritance.

Secondly, one could point to the eclipse of the grande bourgeoisie as a class in which economic power was personalised and inheritable. In the wake of globalisation, economic power gets depersonalised and delocalised. The new global players have their headquarters somewhere in the CBD but, unlike Krupp-the industrial tycoon of the Ruhr residing in the Villa Hügel in Essen-Credit Suisse or a hedge fund does not have a 'family home'. Economic power is only temporarily bound to specific individuals and it is less and less inheritable. CEOs of 
global companies mostly take office only for a couple of years and then leave for the next challenge. Hence, their ability to imprint their personal habits and tastes on the cityscape durably is diminished.

Debates about the social division of space and the phenomena of social fragmentation and spatial polarisation focus mostly on the bottom end of the social strata. The global city literature (see, for example, Sassen, 1991, 2001) emphasises the emergence of the new urban middle class and the rising numbers of low-educated low-income workers. It argues that the competition between these two classes for urban space usually leads to increasing economic inequality between neighbourhoods, residential segregation, gentrification, intensified discrimination and, eventually, to the exclusion of the not-so-well-off from the gentrified neighbourhoods. The analysis presented in this paper (see section 6) gives strong evidence that the phenomenon of competition for urban space occurs not only between the lower and the upper end of the social strata but within the upper stratum as well. Since 'gentrification' theorises the upgrading of low-status neighbourhoods, the term is not suitable either to define theoretically or to capture empirically the social struggle for the most desired locations involving the upper class and the new urban middle class. Instead, we propose the term 'ennoblement'.

The new urban middle class- the nouveaux riches of our time- that infiltrates the former strongholds of the old upper class, does not do this solely in quest of élite housing but in order to 'participate' in the social prestige and social networks of the grande bourgeoisie by living on its turf. The affluent workers invest considerable amounts of economic capital in a home in a traditional grande bourgeoisie neighbourhood in order to transform this economic capital into social and cultural capital and, in doing so, become a part of the upper class. This process can be labelled 'ennoblement'. While in the course of gentrification a low-status area is upgraded by pioneers and their hip scene and later on by more well-off residents, ennoblement works the other way around: here, the historically accumulated prestige of an upper-class area helps the newcomers to achieve a higher status. While the process of gentrification implies the transformation of social and cultural capital into rising real estate values and with that into economic capital, ennoblement means the transformation of economic capital into social and cultural capital.

The city functions as an 'exchange office' via the dynamics of the real estate market by transforming one of Bourdieu's types of capital into another one. Intelligent developers have known this for a long time and consequently tempt artists, musicians and students with low rents into their run-down, deteriorating locations, hoping that these, as pioneers, initiate a vibrant scene which later on leads to an 'in-quarter' with rising real estate values. Subsequently, the pioneers are priced out of the area. Yet if the city functions as an exchange office by turning cultural into economic capital, it is by no means certain whether this process works as reliably the other way round.

In Zurich the intrusion of the new urban middle class into grande bourgeoisie neighbourhoods has been accompanied by a doubling in the prices of condominiums. However, more dangerous than rising prices in the quest by the new affluent workers for higher social status are the implications following from the densification of these neighbourhoods, affecting not only the built environment but also the social prestige of such areas. Even though the condominiumisation of grande bourgeoisie neighbourhoods by infill housing and/or the replacement of older buildings seems at first glance to be a 'success story', one has to be aware that 'success might devour its children': the social and spatial transformation of grande bourgeoisie 
neighbourhoods in the course of the intrusion of the new urban middle class is not only a distinct sign of the attenuation of $l a$ griffe spatiale but might gradually undermine the very prestige of the neighbourhood. By remodelling a grande bourgeoisie neighbourhood to the aspirations of the new urban middle class, the socioeconomic structure of the neighbourhood is inevitably changing, deteriorating in the sense that visible symbols of an exclusive upper-class area are being lost. The social and cultural capital that the grande bourgeoisie neighbourhood captured in the past is being denounced as the nouveaux riches have successfully established residence. The invasion may have the qualities of a Pyrrhic victory.

\section{Notes}

1. The results for the lower pole do not fit in the global city theory, because the proportion of workers in the lower ranks fell from 19.0 per cent to 10.7 per cent, which does not match the hypothesis of socio-spatial polarisation. Yet this contradictory result has to be relativised for three reasons: First, because of change in the survey methods. In 1990, the information forming the socio-professional status was still estimated by the interviewer, who actually called upon the interviewee. For the census count of 2000 , in contrast, a questionnaire was mailed out and the respondents filled in the information on socio-professional status themselves. As a consequence, socio-professional status for one-quarter of the questionnaires could not be classified. This explains the increase in the 'unclassifiable' category, from 8.9 per cent in 1990 to 24.9 per cent in 2000. Because the 'unclassifiable' category also correlates strongly with little or no education/training, the majority of these cases could be assigned to the low-qualifications pole. If all of the nearly 25 per cent of unclassifiable cases were to be assigned to this pole, then the result would actually be distinct growth in the lower pole. Secondly, in the same time-frame, the number of unemployed people rose from 4856 (2.4 per cent) to 12279 , or 6.1 per cent (Statistik
Stadt Zürich, 2005b). At the same time, the percentage of low-status migrants (as defined in the text) grew between 1993 and 2002 by 3 percentage points. Here it also appears to be very plausible that the majority of both these groups should be assigned to the lower qualification pole. Thirdly, it is highly plausible that a large portion of mainly unskilled and household services were performed by low-status migrants and informally (i.e. informal sector), without appearing in the official statistics. All three arguments suggest that the percentage of the working population represented by the lower levels of the employment pyramid were systematically underestimated in the census of 2000.

2. The statistic records the renovation of a building if it is the subject of authorisation-i.e. if an official permit is required. Although in other countries, informal practices of renewal, extension or renovation might be an important part of the alteration of and additions to the residential housing stock, in Switzerland this cannot be observed. Switzerland is renowned for its legalist habitus and social control through neighbours and this is especially true for housing investments. Depending on its physical dimension (in $\mathrm{cm}$ ), even façade isolation requires permission. The city of Zurich controls physical change to building stock very strictly and declares that noteworthy illegal changes are investigated and all illegal building activities are fined (and (ex post) recorded) and/or demolished. This also is the experience of the authors. Therefore, we do not give estimates of informal or illegal investments.

3. The rate of homeownership is low in Switzerland-i.e. traditionally, Switzerland is 'a nation of tenants'. In the Canton of Zurich in 2000, homeowners accounted for only about 25 per cent of households. Although in comparison with the rest of Europe Switzerland is still in the tail position, the share of owneroccupied dwellings nation-wide rose from 31 to 35 per cent during the past decade. Since the 1990s, the number of condominiums has increased particularly rapidly. Between 1990 and 2000, an expansion from 4 to 8 per cent has taken place throughout Switzerland. Their share in the city of Zurich in 2005 was at 6.6 per cent of the residential unit stock and 
showed a two-thirds increase over the past 10 years. The share of condominiums in new construction in Zurich in the past few years amounts to about one-quarter and the trend is holding steady. Among the reasons for the increasing demand for owner-occupation are sinking interest rates and the option of early withdrawal of retirement funds.

4. Social capital in this context means to socialise with the 'right' people and cultivate valuable contacts and personal networks (such as membership of clubs and societies, attending gala dinners or charity performances) that are prerequisites for doing 'big business'. Butler (2003, p. 2483) refers to social capital as "the sum of actual and potential resources that can be mobilised through membership in social networks of actors and organisations". Cultural capital includes a cosmopolitan lifestyle (such as speaking a foreign language), participation in cultural life (for example, visiting museums, theatres, operas) and being a client of the art market.

5. However, according to Heye and Leuthold (2006), the patterns and degree of social segregation in the city region and the city are quite similar.

\section{Acknowledgements}

The authors would like to thank Statistik Stadt Zürich for providing the statistical data. They also thank the anonymous referees and the Editor for their valuable comments.

\section{References}

Bourdieu, P. (1983/1992) Ökonomisches Kapital— Kulturelles Kapital-Soziales Kapital, in: M.Steinrücke (Ed.) Dieverborgenen Mechanismen der Macht, pp. 49-80. Hamburg: Vsa Verlag.

Butler, T. G. (2003) Living in the bubble: gentrification and its 'others' in North London, Urban Studies, 40(12), pp. 2469-2486.

Criekingen, M. van and Decroly J. M. (2003) Revisiting the diversity of gentrification: neighbourhood renewal processes in Brussels and Montreal, Urban Studies, 40(12), pp. 2451-2468.

Dahendorf, R. (2005) Selbstbewusste Bürger sind keine Bürger von Staates Gnaden:
Ralf Dahrendorf über die vergangenen Werte des Bürgertums, Neue Zürcher Zeitung, 8/9 October, p. 81.

Florida, R. (2002) The Rise of the Creative Class: And How It's Transforming Work, Leisure, Community and Everyday Life. New York: Basic Books.

Florida, R. (2005) Creative Cities and the Creative Class. London: Routledge.

Friedmann, J. (1986) The world city hypothesis, Development and Change, 17(1), pp. 69-83.

Friedmann, J. and Wolff, G. (1982) World city formation: an agenda for research and action, International Journal of Urban and Regional Research, 6(3), pp. 309-344.

Glass, R. (1964) London: Aspects of Change. London: MacGibbon \& Kee.

Hamnett, C. (1994) Social polarisation in global cities: theory and evidence, Urban Studies, 31(3), pp. 401-424.

Hamnett, C. (1996a) Social polarisation, economic restructuring and welfare state regimes, Urban Studies, 33(8), pp. 1407-1430.

Hamnett, C. (1996b) Why Sassen is wrong: a response to Burgers, Urban Studies, 33(1), pp. 107-110.

Hamnett, C. (2003) Unequal City: London in the Global Arena. London: Routledge.

Harrison, B. and Bluestone, B. (1988) The Great U-turn: Corporate Restructuring and the Polarizing of America. New York: Basic Books.

Häussermann, H. and Siebel, W. (1995) Dienst leistungsgesellschaften. Frankfurt am Main: Suhrkamp.

Hettling, M. (1998) Bürgerlichkeit: Eine ungesellige Geselligkeit, in: M. Hettling, M. König and M. Schaffner (Eds) Eine kleine Geschichte der Schweiz. Der Bundesstaat und seine Traditionen. Frankfurt am Main: Suhrkamp.

Heye, C. and Leuthold, H. (2004) Segregation und Umzüge in der Stadt und Agglomeration Zürich. Zürich: Fachstelle für Stadtentwicklung.

Heye, C. and Leuthold, H. (2006) Sozialräumlicher Wandel in der Agglomeration Zürich, disP: The Planning Review, 164, pp. 16-29.

Hill, R. C. and Kim, J. W. (2000) Global cities and developmental states: New York, Tokyo and Seoul, Urban Studies, 37(12), pp. 2167-2195.

Kronauer, M. (2002) Exklusion: Die Gefährdung des Sozialen im hoch entwickelten Kapitalismus. Frankfurt am Main: Campus. 
Le Galès, P. (2002) European Cities: Social Conflict and Governance. Oxford: Oxford University Press.

Marcuse, P. (1989) Dual city: a muddy metaphor for a quartered city, International Journal of Urban and Regional Research, 17, pp. 355-365.

Marcuse, P. (2004) Verschwindet die europäische Stadt in einem allgemeinen Typus der globalisierten Stadt?, in: W. Siebel (Ed.) Die europäische Stadt, pp. 112-118. Frankfurt am Main: Suhrkamp.

Mollenkopf, J. H. and Castells, M. (Eds) (1991) Dual City: Restructuring New York. New York: Russell Sage Foundation.

Pinçon, M. and Pinçon-Charlot, M. (2000) Sociologie de la bourgeoisie. Paris: Éditions La Decouverte.

Rhein, C. (1998) Globalisation, social change and minorities in metropolitan Paris: the emergence of new class patterns, Urban Studies, 35(3), pp. 429-447.

Sassen, S. (1991) The Global City: New York, London, Tokyo. Princeton, NJ: Princeton University Press.

Sassen, S. (2000) Machtbeben: Wohin führt die Globalisierung? Stuttgart: DVA.

Sassen, S. (2001) The Global City: New York, London, Tokyo, 2nd edn. Princeton, NJ: Princeton University Press.

Siebel, W. (Ed.) (2004) Die europäische Stadt. Frankfurt am Main: Suhrkamp.
Statistik Stadt Zürich (2005a) Deutsche in der Stadt Zürich im Jahr 2004, Daten-Analysen, 3/2005.

Statistik Stadt Zürich (2005b) Jahrbuch 2004. Zürich.

Tanner, A. (2005) Die Schweiz nach der 'Entbürgerlichung': Eine neue Bürgerlichkeit als Lebensmodell für die Zukunft?, Neue Zürcher Zeitung, 8/9 October, p. 82.

Taylor, P. J. (2005) Leading world cities: empirical evaluations of urban nodes in multiple networks, Urban Studies, 42(9), pp. 1593-1608.

Taylor, P. J., Catalano, G. and Walker, D. R. F. (2002) Measurement of the world city network, Urban Studies, 39(13), pp. 2367-2376.

Walks, R. A. (2001) The social ecology of the post-Fordist/global city? Economic restructuring and socio-spatial polarisation in the Toronto urban region, Urban Studies, 38(3), pp. 407-447.

Wezemael, J. E. van (1999) Markt und Wohnen. Diplomarbeit, Universität Zürich.

Zhang, X. and Kanbur, R. (2001) What difference do polarisation measures make? An application to China, Journal of Development Studies, 37(3), pp. 85-98.

Zukin, S. (1987) Gentrification: culture and capital in the urban core, Annual Review of Sociology, 13, pp. 129-147. 